\title{
An Analysis of the Factorial Structure of the Teacher Communication Behavior Questionnaire with Brazilian High School Science Students ${ }^{1}$
}

\author{
Daniel Abud Seabra Matos ${ }^{2}$ \\ Universidade Federal de Ouro Preto \\ Walter Lana Leite \\ University of Florida \\ Gavin Thomas Lumsden Brown \\ The University of Auckland \\ Sérgio Dias Cirino \\ Universidade Federal de Minas Gerais
}

\begin{abstract}
The Teacher Communication Behavior Questionnaire (TCBQ) has been used at different levels of education in many countries to measure students' perceptions of their science teachers' communication behavior. The TCBQ was translated into Portuguese in accordance with ITC test adaptation standards. Validity evidence for the Brazilian version of the TCBQ was obtained with a sample of 414 secondary students. The internal consistency of the TCBQ was satisfactory and an adequate fit of the original factor model was found through confirmatory factor analysis. The Brazilian data exhibited inter-factor correlations similar in value and direction to those of previous international studies. Statistically significant differences were found between school type and subject matter, which is consistent with previous studies.
\end{abstract}

Keywords: student perception, classroom learning environment, science education

\section{Uma Análise da Estrutura Fatorial do Teacher Communication Behavior Questionnaire com Alunos Brasileiros de Ciências no Ensino Médio}

\begin{abstract}
RESUMO - O Teacher Communication Behavior Questionnaire (TCBQ) tem sido usado em níveis de ensino diferentes, em muitos países, com o objetivo de mensurar a percepção dos alunos do comportamento comunicativo do professor de ciências. O TCBQ foi traduzido para o Português de acordo com os padrões de adaptação de testes da ITC. Evidência de validade para a versão brasileira do TCBQ foi obtida com uma amostra de 414 estudantes do ensino médio. A consistência interna do TCBQ foi adequada e um ajuste adequado do modelo fatorial original foi encontrado por meio de análise fatorial confirmatória. Os dados brasileiros apresentaram correlações entre fatores similares, no valor e na direção, às de pesquisas internacionais. Foram encontradas diferenças estatisticamente significantes entre tipo de escola e matéria consistentes com pesquisas anteriores.
\end{abstract}

Palavras-chave: percepção do estudante, ambiente de aprendizagem da sala de aula, ciências

Positive classroom learning environments depend on teachers' interpersonal skills to create positive teacherstudent relationships (Wubbels, Levy, \& Brekelmans, 1997). Classroom learning environments have received substantial attention from researchers, teachers, and schools (Dorman, 2002). At least ten different psychometrically-evaluated inventories have been reported as means of obtaining students' perceptions of the quality of the classroom learning environment (Chen, Chang, \& Chang, 2002; Fraser, 2002; Idiris \& Fraser, 1994; She \& Fisher, 2000; Sebela, 2003; Waldrip \& Fisher 2000; Walker, 2004; Wubbels \& Levy, 1991). These scales have been used to assess the quality of classroom learning environments in North America, Europe, Asia, and Africa. Despite this internationalization, we noted the absence of instruments to measure students' perceptions

1 Apoio: Fundação de Amparo à Pesquisa do Estado de Minas Gerais (FAPEMIG)

2 Endereço para correspondência: Departamento de Educação, Universidade Federal de Ouro Preto, Instituto de Ciências Humanas e Sociais, Rua do Seminário, $\mathrm{s} / \mathrm{n}^{\circ}$ Centro, Mariana, MG, Brasil. CEP: 35420-000.E-mail: danielmatos@ichs.ufop.br of the classroom learning environment for use in South American countries.

Among these scales, the Teacher Communication Behavior Questionnaire (TCBQ) assesses both verbal and non-verbal communication between teachers and students. The TCBQ has been validated with Taiwanese and Australian samples and used in the United States, United Kingdom, and Turkey. In this study, our primary goal is to adapt the student version of the TCBQ for use in Brazilian high school classrooms. Additionally, we examine the factor structure of the TCBQ with confirmatory factor analysis (CFA), an advanced psychometric method that has not previously been reported for this scale. Therefore, the version of the TCBQ we develop in this study contributes to research tools for measuring classroom learning environments in Portuguesespeaking contexts, as well as adding to the body of validation studies for the TCBQ inventory.

To evaluate the TCBQ adaptation for use with Brazilian high school students, the Brazilian results were analyzed with CFA to determine if the five-factor structure could be recovered and if the scale statistics were comparable to previous studies from different countries and languages. 
Additionally, the study provides a preliminary evaluation of whether student perceptions of teacher communication behaviors in Brazilian high school classrooms depend on the gender of the student, gender of the teacher, type of school (i.e., public or private), and subject matter (i.e., biological science or physical science).

The following sections contain (1) a review of the theoretical framework underpinning the TCBQ and (2) an evaluation of the scale reliability estimates and inter-scale correlations obtained in different countries.

\section{Theoretical framework}

Within the broad research area of classroom learning environments, concern regarding the study of teacher-student relationships has been based largely on the work of Wubbels (Wubbels \& Brekelmans, 2005; Wubbels \& Levy, 1991; Wubbels et al., 1997). Wubbels was interested in teacherstudent relationships from a systems theory perspective (Watzlawick, Beavin, \& Jackson, 1991). Systems theory emphasizes the connections between a group of individuals and the feedback mechanisms by which the individuals mutually influence each other. Social situations are defined as systems because changes in one aspect of the system cause changes in other aspects. The systems perspective implies that teacher-student relationships are not unidirectional. That is, the teacher's and students' behaviors mutually and partially determine and are determined by each other.

Furthermore, everything that happens in a classroom can be considered communication (e.g., students' silence during class, non-verbal behaviors, indiscipline, etc.). Wubbels developed a model for interpersonal teacher behavior based on two dimensions of the teacher-student relationship,influence and proximity. The influence dimension varies from dominance to submission, while the proximity dimension varies from opposition to cooperation. Based on these dimensions, Wubbels created a taxonomy of eight types of teacher behavior: (a) leading, (b) helpful/ friendly, (c) understanding, (d) student responsibility/ freedom (e.g., giving freedom and responsibility for the students or giving opportunity for independent work), (e) uncertain, (f) dissatisfied, (g) admonishing, and (h) strict (Wubbels \& Brekelmans, 2005). To measure these behavior types, Wubbels and Levy (1991) developed the 77-item Questionnaire on Teacher Interaction (QTI) which has been translated into several languages.

She and Fisher $(2000,2002)$ developed the Teacher Communication Behavior Questionnaire (TCBQ) from the QTI. The development of the TCBQ was also based on She's studies of teacher-student interactions in Taiwanese science classrooms (She, 1998, 1999, 2000). For instance, She (2000) analyzed teacher-initiated questions, student responses, and teacher feedback in two $7^{\text {th }}$-grade biology classes. The study reported that male students answered teacher-initiated questions at a much higher frequency than female students and received more frequent feedback from the teacher (She, 2000). Important aspects of this and other studies, such as type of questions in the classroom, teacher- initiated questions, and teacher-student relationship (i.e., feedback and support), were used to create the TCBQ scales.

The TCBQ measures students' perceptions of science teachers' communication behavior with five scales: (a) challenging (i.e., extent to which the teacher uses higherorder questions to challenge students in their learning), (b) encouragement and praise (i.e., extent to which the teacher praises and encourages the students), (c) non-verbal support (i.e., extent to which the teacher uses non-verbal communication to interact positively with the students), (d) understanding and friendliness (i.e., extent to which the teacher is understanding and friendly towards students), and (e) controlling (i.e., extent to which the teacher controls and manages student behavior in class) (She \& Fisher, 2000, 2002). The questionnaire has 40 items (see Appendix A) with 8 items for each scale. The students responded on a 5-point frequency scale: $1=$ almost never, $2=$ seldom, $3=$ sometimes, $4=$ often, and $5=$ very often.

The TCBQ was developed simultaneously in Australia and Taiwan to assess student perceptions of their science teachers' communication behaviors. We chose to adapt this instrument to Brazilian classrooms because of its comprehensive coverage of student perceptions of teachers' verbal and non-verbal behaviors and attitudes. The TCBQ can be used to provide teachers with feedback about their behaviors in the classroom and facilitate the improvement of classroom environments. Two forms of the TCBQ have been developed, one for students and another for teachers (She, 2000). We focus on the student version because it is particularly useful for gaining insights into how students perceive the teachers' communication behaviors. Receiving feedback on the five aspects of teacher-student relationship is most useful for teacher continuous professional learning.

Researchers have used classroom learning environment dimensions (e.g., size of class, type of school, grade level, and subject matter) as independent variables in studies of variation in classroom environments. For example, the effect of student gender is most widely studied in Asia (Fraser, 2002), with the results showing that girls, compared to boys, tend to (a) perceive their learning environments more positively (Fraser, Giddings, \& McRobbie, 1995; Khine \& Fisher, 2003; She \& Fisher, 2002), (b) report higher levels of encouragement and praise (Frumkin, 2006), (c) have more positive perceptions of all five TCBQ factors (Frumkin \& Murphy, 2007), and (d) perceive their teachers as providing more encouragement and praise and exhibiting greater understanding and friendlier behaviors (Özay, Kaya, \& Sezek, 2004; Yilmaz Tüzün, 2006). In contrast, male students have reported to perceive their teachers as more controlling (Yilmaz Tüzün, 2006).

There is evidence of positive associations between students' cognitive learning outcomes and their perceptions of the classroom learning environment (Fraser, 2002). As expected, subject matter has been found to influence student perceptions. Perhaps the reason being that biological science is considered a somewhat easier option than physical sciences, and is often taught in a less traditional fashion than physics, biology teachers have been more positively perceived than physics teachers (Özay et al., 2004; She, 1998; She \& Fisher, 2002). 
With respect to the differences between the students' perceptions of their male and female teachers, several studies found no significant interactions between teachers' gender and students' gender (Fagot, 1981; Stake \& Katz, 1982). However, studies employing the TCBQ found interactions between teachers' gender and students' gender. For example, Cirillo and Herbel-Eisenmann (2006) found that male students rated their male teachers higher on all factors and female students rated their female teachers higher on all TCBQ factors. Frumkin and Murphy (2007) reported no difference between teachers' gender, but found that female, rather than male students, rated both male and female teachers higher on all TCBQ factors. environment', and 'student representation' and 'classroom learning environment'. Studies were selected if they directly used the TCBQ to collect data and provided reliability information. Although two of the studies did not report internal consistency estimates for the TCBQ scales, this information was obtained from the corresponding authors. A total of seven studies meeting these criteria were identified (see Table 1).

The TCBQ's use in five countries included all levels of education, although mostly were in science classes. Two studies involved distance education programs (Frumkin, 2006; Frumkin \& Murphy, 2007). Frumkin (2006) reported a virtual learning environment (VLE) study of 86 students (53

Table 1. TCBQ studies from six countries

\begin{tabular}{|c|c|c|c|c|}
\hline Authors & Country & Sample size & Level & Subject \\
\hline She \& Fisher, 2000 & $\begin{array}{c}\text { Australia and } \\
\text { Taiwan }\end{array}$ & $\begin{array}{l}1202 \text { (Taiwan) } \\
301 \text { (Australia) }\end{array}$ & $\begin{array}{c}\text { Secondary } \\
\text { (grades } 7 \text { to 9) }\end{array}$ & Science classes \\
\hline She \& Fisher, 2002 & $\begin{array}{c}\text { Australia and } \\
\text { Taiwan }\end{array}$ & $\begin{array}{l}1138 \text { (Taiwan) } \\
307 \text { (Australia) }\end{array}$ & $\begin{array}{c}\text { Secondary } \\
\text { (grades } 7 \text { to 9) }\end{array}$ & $\begin{array}{c}\text { Biological / physical } \\
\text { science }\end{array}$ \\
\hline Özay, Kaya \& Sezek, 2004 & Turkey & 389 & $\begin{array}{c}\text { Secondary } \\
\text { (grades } 7 \text { to 9) }\end{array}$ & $\begin{array}{l}\text { Biological / chemical } \\
\text { / physical science }\end{array}$ \\
\hline Yilmaz Tüzün, 2006 & Turkey & 751 & $\begin{array}{l}\text { Elementary } \\
\text { (grades } 4 \text { to } 8 \text { ) }\end{array}$ & Science classes \\
\hline Cirillo \& Herbel-Eisenmann, 2006 & USA & 178 & $\begin{array}{c}\text { Secondary } \\
\text { (grades } 7 \text { to 10) }\end{array}$ & Mathematics \\
\hline Frumkin, 2006 & United Kingdom & 86 & $\begin{array}{c}\text { Tertiary } \\
\text { (MSc students) }\end{array}$ & $\begin{array}{l}\text { Computing } \\
\text { Science }\end{array}$ \\
\hline Frumkin \& Murphy, 2007 & United Kingdom & 113 & $\begin{array}{c}\text { Tertiary } \\
\text { (MSc students) }\end{array}$ & $\begin{array}{l}\text { Computing } \\
\text { Science }\end{array}$ \\
\hline
\end{tabular}

\section{Studies using the TCBQ}

A broad literature search was carried out among international databases (i.e., Academic Search Premier, Mental Measurements Yearbook, Professional Development Collection, PsycINFO, Psychology and Behavioral Sciences Collection, and Research Starters - Education), as well as on Brazilian databases (i.e., Scielo, Pepsic), for keywords 'Teacher Communication Behavior Questionnaire' and "TCBQ". We also searched the following combinations of keywords: 'student conception' and 'classroom learning environment', 'student perception' and 'classroom learning
Asian and 33 Caucasian) who lived in the United Kingdom or had recently moved there. Frumkin and Murphy (2007) investigated a distance learning project originated at a British university involving a sample of 113 students (47 citizens of European Union countries and 66 Chinese students). Because these studies used participants living in different countries, results reflected complex cross-cultural differences among students and teachers, rather than being robust indicators of TCBQ factors in the host countries. Consequently, the statistical properties of the TCBQ are reported for just four countries for which we can be confident of the participant nationalities (Table 2).

Table 2. Comparison of TCBQ psychometric properties in samples from four countries

\begin{tabular}{|c|c|c|c|c|c|c|c|c|c|}
\hline \multirow[b]{2}{*}{ TCBQ Scale } & \multicolumn{4}{|c|}{ Cronbach's alpha coefficients } & \multicolumn{5}{|c|}{ Mean inter-correlation with other scales } \\
\hline & Australia & Taiwan & Turkey & USA & Australia & Taiwan & Turkey & USA & Mean \\
\hline Challenging & .86 & .88 & .70 & .85 & .37 & .40 & .62 & .53 & .48 \\
\hline $\begin{array}{l}\text { Encouragement \& } \\
\text { praise }\end{array}$ & .87 & .91 & .77 & .90 & .44 & .50 & .61 & .57 & .53 \\
\hline Non-verbal support & .92 & .93 & .86 & .93 & .44 & .50 & .51 & .55 & .50 \\
\hline $\begin{array}{l}\text { Understanding \& } \\
\text { friendly }\end{array}$ & .93 & .92 & .86 & .94 & .39 & .47 & .54 & .52 & .48 \\
\hline Controlling & .87 & .87 & .76 & .87 & .05 & .14 & .19 & .31 & .17 \\
\hline
\end{tabular}

Note. Sample sizes: Australia ( $\mathrm{n}=307)$, Taiwan $(\mathrm{n}=1138)$, Turkey $(\mathrm{n}=751)$, USA $(\mathrm{n}=178)$ 
Evidently, the Cronbach's alpha coefficients were consistently high for all scales in four countries (i.e., ranging between .83 and .94), with the exception of Turkey where values ranged from .70 to .86 . Nevertheless, these studies demonstrated that the TCBQ scales had sufficiently similar and robust internal estimates of reliability despite differences in language and geography.

In the development of the TCBQ, She and Fisher (2002) reported the mean inter-scale correlations for each TCBQ scale as evidence of discriminant validity. Correlations ranged from .05 to .62 , depending on the country. These values can be considered small enough to confirm the independence of each scale; hence, the structure of the TCBQ as five distinct factors is supported. However, none of the international studies reviewed employed CFA to examine the factorial structure of the TCBQ. Thus, the goal of this study was to analyze the underlying dimensions of the TCBQ with confirmatory factor analysis, a powerful psychometric technique for identifying dimensionality (Hoyle \& Duvall, 2004).

\section{Method}

In this section, we describe how we adapted the TCBQ for use with Brazilian students ${ }^{1}$ following the guidelines from the International Test Commission (ITC, 2000b) and collected valid evidence according to established test development standards (AERA, APA, \& NCME, 1999).

\section{Adaptation of the TCBQ}

Test developers should (a) provide evidence that item content is familiar to all intended populations; (b) insure that the adaptation process takes full account of linguistic and cultural differences among the populations; and (c) implement systematic judgmental evidence, both linguistic and psychological, to improve the adaptation process (ITC, 2000b). Hence, validity evidence for the translated questionnaire with respect to scale content and response process was obtained through three qualitative procedures (i.e., back translation from Portuguese to English, interviews with prospective users of the questionnaire, and pilot administration of the Brazilian questionnaire). Then, we conducted a large-scale administration of the TCBQ to obtain validity evidence with respect to the scale's internal structure using CFA and estimation of scale reliability coefficients.

The TCBQ was translated from English to Portuguese for use in Brazil. Back translation procedure is a commonlyused procedure to evaluate the quality of a translation (Harkness \& Schoua-Glusberg, 1998). The first and fourth authors of the present study translated the English TCBQ into Portuguese and back translations into English were performed independently by three researchers not involved in the original translation. Based on the results of the back-

1 This research was submitted to the Ethics Committee of the Universidade Federal de Minas Gerais (process number 163-05) and followed all the rules and guidelines contained in Resolution 196/96. translation, some modifications were made to the wording of the items in the Brazilian version to match more closely the functional meaning of the English version. For instance, the first translation of item 19 was "sem falar, esse professor (a) demonstra apoio para mim pela sua expressão facial". After the back-translation procedure, the item was modified to "sem falar, esse professor (a) demonstra, pela sua expressão facial, que me apoia".

Next, feedback from potential future users of the questionnaire was obtained. Ten $9^{\text {th }}$ grade science students from three different Brazilian schools were interviewed. The students were distributed into three groups. The first group contained four boys from a private school, the second group contained four girls from a second private school, and the third group contained two girls from a public school. The objective of the interviews was to obtain insights as to how the students understood the questionnaire, its sub-scales, and items. We also obtained fresh points of view from the students about their classes and their answers to the questions.

Subsequently, a pilot administration of the Brazilian TCBQ was conducted in one classroom of 33 students in a public secondary school. This procedure confirmed that students did not have any problems understanding and responding to the adapted Brazilian TCBQ. These three procedures provided sufficient evidence that the Brazilian version of the TCBQ was equivalent to the English version and that the items were appropriate for administration to Brazilian secondary school science students.

The ITC (2000a) guidelines also require the use of appropriate statistical techniques to establish the equivalence of the different versions of the instrument. To establish that the scale scores of an adapted instrument are valid and reliable, factor analytic, experimental or other correlational information can be used (Hambleton \& Patsula, 1999). Thus, we collected data for a CFA of the Brazilian TCBQ through a survey of $4149^{\text {th }}$ grade science students. The translated items for the TCBQ are provided in Appendix A.

\section{Participants}

Responses to the TCBQ were obtained from a large, nonrandom sample of Brazilian science students enrolled in 9th grade, the first year of secondary education, $(N=414 ; 195$ males and 219 females; age $M=15.33$ years; $S D=.71$ ). Five of nine invited schools, all located in Belo Horizonte, the third largest city in Brazil, provided students from: private school A $(n=18)$; public school B $(\mathrm{n}=102)$; private school $\mathrm{C}(n=91)$; public school D $(n=130)$; and private school $\mathrm{E}(n=73)$. Thus, the students were split relatively evenly between public $(n=232)$ and private $(n=182)$ schooling (details in Table 3). In Brazilian standardized tests for primary and secondary education, the mean academic achievement scores of private school students are generally higher than those of public schools students. While no studies with the TCBQ have examined the relationship between achievement and type of school, assuming that teacher communication style is a predictor of performance, teachers in private schools would be viewed more positively because of the higher academic success in that environment. The Brazilian 
Table 3. Participants in Brazilian TCBQ study

\begin{tabular}{lccc}
\hline & \multicolumn{2}{c}{ Student gender } & \\
\hline \multicolumn{1}{c}{ Demographic Factor } & Female & Male & Total \\
\hline $\begin{array}{l}\text { Type of School } \\
\text { Private }\end{array}$ & 97 & 85 & 182 \\
Public & 122 & 110 & 232 \\
Science Subject Studied & & & \\
$\quad$ Biological Science & 113 & 120 & 233 \\
Physical Science & 106 & 75 & 181 \\
Teacher Gender & & & 227 \\
Female (n=7) & 114 & 113 & 187 \\
Male (n=6) & 105 & 82 & \\
Total & 219 & 195 & \\
\hline
\end{tabular}

secondary science curriculum divides the subject area into three separate courses: biology $(n=233)$, physics $(n=181)$, and chemistry (not included in our study).

The students had 13 teachers ( 7 female and 6 male), but more students had a female teacher $(n=227)$ than a male teacher $(n=187)$ (see Table 3$)$.

\section{Data Analysis}

The software MPLUS version 4.2 (Muthén \& Muthén, 2006) was used for this analysis. The CFA was conducted using the mean and variance-adjusted weighted least squares estimator (WLSMV). Standard errors were obtained with Taylor Series linearization (Stapleton, 2006) to account for clustering effects due to students being grouped within classrooms. The equation of the CFA model used was $\gamma_{i j}=$ $\lambda_{i k} n_{i k}+\varepsilon_{i j}$, where $i$ indicates a student, $j$ indicates an item, $k$ indicates each of the factors of the TCBQ, $\gamma_{i j}$ corresponds to the observed score of a student on an item, $\lambda_{j k}$ is the loading of an item on a factor, $n_{i k}$ is the factor score of a student on a factor, and $\varepsilon_{i j}$ is a residual error.

In order to evaluate model fit, the $\chi 2$ statistic and multiple fit indices (i.e. CFI, TLI, gamma hat, RMSEA, and SRMR) were examined (Fan \& Sivo, 2007; Hu \& Bentler, 1999). Recently, it has been shown that $\mathrm{Hu}$ and Bentler's criteria are too restrictive when applied to multi-factor rating instruments (Marsh, Hau, \& Wen, 2004; Marsh, Hau, \& Grayson, 2005). The criteria of CFI $\geq .90, \mathrm{TLI} \geq .90$, gamma hat $\geq .90$, RMSEA $\leq .08$ and $\mathrm{SRMR} \leq .08$ were used to establish adequate fit, rather than the more strict cutoff criteria proposed by $\mathrm{Hu}$ and Bentler (1999).

There have been no previously reported studies of the TCBQ in Brazil. Thus, we evaluate in this paper whether TCBQ results found in other countries generalize to Brazil. We tested four hypotheses about main effects and one hypothesis about a two-way interaction using the scores on the TCBQ factors from the Brazilian sample.

1. Main effect of student gender: Female students would perceive their learning environments more positively than male students.

2. Main effect of type of school: Students in private schools would have more positive perceptions of TCBQ than public school students.

3. Main effect of subject matter: Biological science students would perceive their learning environments more positively than physical science students.

4. Main effect of teacher gender: Students would have more positive perceptions of female teachers than male teachers.

5. Interaction between student gender and teacher gender: Male students would have more positive perceptions of male teachers, while female students would have more positive perceptions of female teachers.

A structural equation model (SEM) was used to test these hypotheses, because it allows the estimation of the effects (and interactions) of the independent variables upon the latent constructs controlling for measurement error in the indicators. Thus, in our model, each of the five inter-correlated TCBQ factors was predicted by student gender, type of school, subject matter, teacher gender, and interaction between student gender and teacher gender. The equation for the SEM was:

$$
\begin{aligned}
& \gamma_{i j}=\lambda_{j k} n_{i k}+\varepsilon_{i j} \\
& n_{i k}=\beta_{0 k}+\beta_{1 k} X_{1 i}+\beta_{2 k} X_{2 i}+\beta_{3 k} X_{3 i}+\beta_{4 k} X_{4 i}+\beta_{5 K} X_{1 i} X_{4 i}+\zeta_{i k}
\end{aligned}
$$

where the first equation is the measurement part of the model with terms as defined previously, and the second equation is the structural part of the model. In this model (Figure 1), $n_{i k}$ is the student score on a TCBQ factor, $\beta_{0_{k}}$ is the factor's intercept, $X_{1 i}$ indicates student gender, $X_{2 i}$ indicates type of school, $X_{3 i}$ indicates subject matter, $X_{4 i}$ 


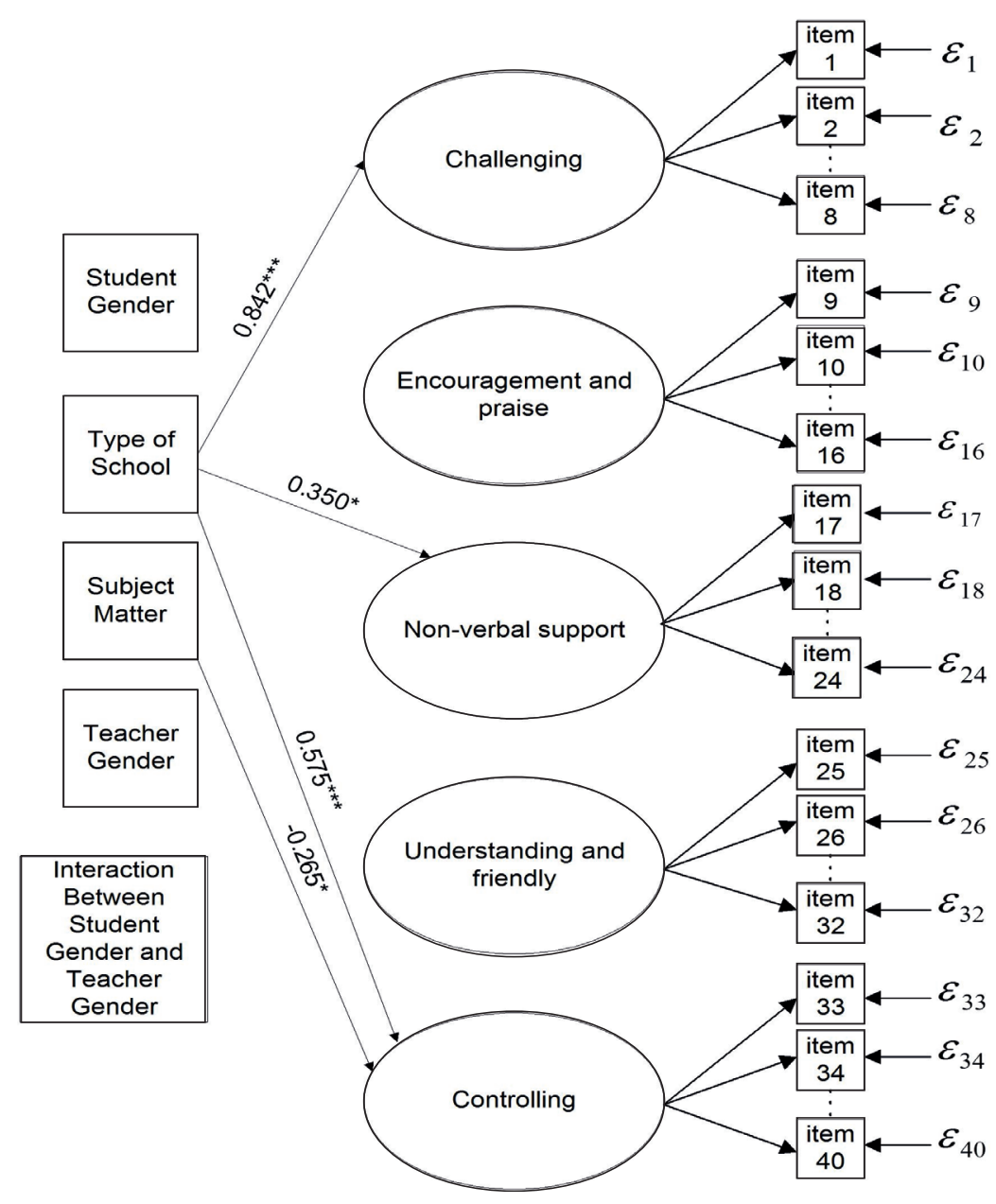

Figure 1. Structural equation model of the effects of covariates on the factors measured by the TCBQ. Note. Only the estimates that were statistically significant are shown. $* \mathrm{p}<$ $.05, * * * \mathrm{p}<.001$. The values shown are the statistically significant effects of covariates.

indicates teacher gender, and the product term $X_{1 i} X_{4 i}$ is the interaction between student gender and teacher gender. All of the predictors were included in the model as dummy-coded variables. The effect of these predictors on the TCBQ factors are shown in $\beta_{1 k}, \beta_{2 k}, \beta_{3 \kappa}, \beta_{4 k}$, and $\beta_{5 \kappa^{*}}$. Analysis of the SEM model followed the same procedures and standards to the CFA presented previously.

\section{Results}

\section{Factorial structure}

A set of alternative models was tested ranging from a one-factor solution to the hypothesized five-factor solution. Our criterion to create alternative models was to use the correlations between scales to create alternative groupings. For instance, because "controlling" had low correlations with all other factors, the two-factor model isolated "controlling" and aggregated the other factors. The fit of alternative models to the data were not as strong as the hypothesized model (Table 4). All other combinations of factors did not have a fit as good as the five-factor model. The hypothesized five-factor CFA model had acceptable fit to the data $(\chi 2=502.094 ; d f=$ $127 ; \mathrm{CFI}=.91 ; \mathrm{TLI}=.97$; gamma hat $=.96$; $\mathrm{RMSEA}=.084)$.

Hence, these results supported the argument that the Brazilian TCBQ responses fit closely to the original TCBQ five-factor structure. The standardized factor loadings for all items of the five-factor TCBQ are reported in Table 5, and show that most items had high factor loadings.

We estimated the factor inter-correlations for the five-factor solution (Table 6). The lowest correlation was between the "Controlling" and the "Encouragement and Praise" factors. The highest correlations were between the "Non-verbal support" and the "Understanding and Friendly" and "Encouragement and praise" factors. These higher correlations indicate that teachers were perceived as providing encouragement and praise, being understanding and friendly, and using non-verbal behaviors.

On one hand, the factor "Non-verbal support" had high correlations with two other factors and these correlations were not as expected (i.e., they did not provide discriminant 
evidence of the scores of Brazilian version of the TCBQ). On the other hand, our CFA results supported the multidimensionality of the five-factor model; indeed, aggregating the factors "Non-verbal support", "Understanding and Friendly", and "Encouragement and praise" together (i.e., three-factors model, Table 4) gave worse fit. or negative to the two remaining teacher communication behaviors (i.e., "Non-verbal support" and "Encouragement and praise"). These scales were much more weakly endorsed than the first three scales (i.e., mean differences were $d=.73$ ). Clearly, from the student perspective, teachers were much more perceived as being challenging, controlling,

Table 4. Comparison of TCBQ CFA models

\begin{tabular}{lcccccc}
\hline \multicolumn{1}{c}{ Models } & $\chi^{2}$ & $\boldsymbol{d} \boldsymbol{f}$ & CFI & TLI & Gamma hat & RMSEA \\
\hline 1 factor & 1975.254 & 121 & .53 & .83 & .82 & .192 \\
2 factors & 1049.067 & 117 & .76 & .91 & .90 & .139 \\
3 factors & 744.455 & 120 & .84 & .94 & .93 & .112 \\
4 factors & 806.945 & 123 & .83 & .94 & .92 & .116 \\
5 factors & 502.094 & 127 & .91 & .97 & .96 & .084 \\
\hline
\end{tabular}

Note: all chi-square values statistically significant $(\mathrm{p}<.0000)$.

Table 5. Standardized factor loadings of TCBQ items

\begin{tabular}{cccccccccc}
\hline \multicolumn{2}{c}{ Challenging } & \multicolumn{2}{c}{ E \& P } & \multicolumn{2}{c}{ NV support } & \multicolumn{2}{c}{ U \& F } & \multicolumn{2}{c}{ Controlling } \\
\hline Item & Loading & Item & Loading & Item & Loading & Item & Loading & Item & Loading \\
\hline 1 & .55 & 9 & .70 & 17 & .65 & 25 & .76 & 33 & .63 \\
2 & .74 & 10 & .79 & 18 & .78 & 26 & .69 & 34 & .74 \\
3 & .67 & 11 & .67 & 19 & .85 & 27 & .71 & 35 & .73 \\
4 & .63 & 12 & .76 & 20 & .82 & 28 & .70 & 36 & .66 \\
5 & .67 & 13 & .79 & 21 & .81 & 29 & .72 & 37 & .71 \\
6 & .74 & 14 & .82 & 22 & .82 & 30 & .81 & 38 & .54 \\
7 & .73 & 15 & .81 & 23 & .81 & 31 & .85 & 39 & .72 \\
8 & .60 & 16 & .77 & 24 & .79 & 32 & .85 & 40 & .72 \\
\hline
\end{tabular}

Note. $\mathrm{E} \& \mathrm{P}=$ Encouragement and praise; NV support = non-verbal support; $\mathrm{U} \& \mathrm{~F}=$ Understanding and friendly.

Furthermore, the Brazilian data seem to exhibit interfactor correlations similar in value and direction to those of previous international studies with the TCBQ. However, the other international studies provided only mean correlations. Thus, we cannot be sure if all the correlations are really in the same direction as those of the present study. The scale estimates of reliability (Table 6) were also close to values reported in previously published studies and similarly high for all scales.

\section{Understanding science students' evaluations of teacher communication behavior}

The mean scores for the five scales (Table 6) indicated that the Brazilian science students in this study generally endorsed three behaviors (i.e., "Challenging", "Understanding and friendly" and "Controlling"). Agreement levels were very similar (i.e., mean difference in agreement between scales was $d \leq|.10|$ ). In contrast, the students were either neutral and understanding than they were seen as encouraging and praising.

The SEM had good fit to the data $(\chi 2=1164.645 ; d f=905$; $\mathrm{CFI}=.97 ; \mathrm{TLI}=.96 ; \mathrm{RMSEA}=.026)$. The results of the SEM showed significant differences between public and private schools on the Challenging scale (standardized $\beta=0.842$, $p<.001$ ), on the non-verbal support scale (standardized $\beta$ $=0.350, p=.03$ ), and on the Control scale (standardized $\beta$ $=0.575, p<.001)$. These values indicate that students in private schools perceived that they received more challenging behaviors, more non-verbal support, and more controlling behaviors from their teachers than students in public schools. Students in biological science perceived more controlling behaviors from their teachers than physical science students (standardized $\beta=-0.265, p=.021$ ). There were no effects for student gender, teacher gender, or interaction between student and teacher gender. 
Table 6. Scale statistics and inter-correlations for the Brazilian TCBQ

\begin{tabular}{lcccccccc}
\hline & & \multicolumn{3}{c}{ Scale Intercorrelations } & \multicolumn{3}{c}{ Scale Statistics } \\
\hline TCBQ Scales & I & II & III & IV & V & Mean & M & SD \\
& & & & & & $r$ & & \\
\hline I. Challenging & $(.83)$ & .55 & .59 & .58 & .45 & .54 & 3.65 & .75 \\
II. Encouragement and praise & & $(.89)$ & .76 & .64 & .19 & .54 & 2.81 & .99 \\
III. Non-verbal support & & & $(.91)$ & .80 & .20 & .59 & 3.13 & .99 \\
IV. Understanding and friendly & & & & $(.89)$ & .20 & .56 & 3.67 & .88 \\
V. Controlling & & & & $(.83)$ & .26 & 3.73 & .76 \\
\hline
\end{tabular}

Note: Cronbach alpha estimate of scale reliability displayed in brackets on diagonal of inter-correlation matrix; correlations estimated with Confirmatory Factor Analysis (CFA).

\section{Discussion}

The TCBQ has been recommended as a robust way of obtaining feedback that can contribute to improvement in classroom learning environments (She \& Fisher, 2000) with successful studies in multiple languages at all levels of education in many different countries. The results of this study support extending the use of the TCBQ to Brazil. CFA recovered the intended five-factor solution with reasonable inter-factor discrimination and strong scale reliability. Therefore, this study has broadened the international applicability of the TCBQ.

We found no difference between female and male students' perceptions of their learning environments. This result differed from previous international studies which showed that girls tend to be more positive than boys (Fraser et al., 1995; Khine \& Fisher, 2003; She \& Fisher, 2002). From the perspective of teacher professional development, this is an encouraging result since schooling effectiveness ought not to depend on learner demographic characteristics.

We found that students perceived that biological science teachers showed more controlling behaviors than physical science teachers. Thus, biological science students perceived their learning environments more positively than do physical science students (the higher the scores on factors, the more positive is the perception). The controlling factor, specifically, means that the teacher makes clear his/her instructions/rules and knows how to control and manage students' behaviors in the classroom. This result reinforces previous international studies which show that biology teachers were more positively perceived than physics teachers (Özay et al., 2004; She \& Fisher, 2002). There are several possible explanations for this subject matter difference. For instance, She (1998) reported that in Taiwan physical science tends to be perceived as more abstract and difficult. On the contrary, the biology content is considered more pertinent to the students' daily lives and biology teaching seems to have a larger variety of approaches. Özay et al. (2004) reached similar conclusions in Turkey. Alternately, if biology is taken by academically weaker students, teachers may need to exercise greater control of classroom behavior than in classrooms where highly-able students self-regulate their learning. Hence, in Brazil, we speculate that our result may be more related to the challenges of managing the classroom, rather than to the subject's inherent difficulty. Further studies are needed to test this speculation.
We also found that private school students perceived their teachers more favorably than did public school ones. These groups had the largest differences identified in this study. The comparison between public and private schools is relevant to the Brazilian context. With Brazil's National Evaluation System of Basic Education (from Portuguese, Sistema de Avaliação da Educação Básica - SAEB), the mean academic achievement scores of private school students are generally higher than that of public schools students. Although our study did not investigate the relation between learning environments and academic achievement in Brazil, it is possible that students of Brazilian private schools have more positive perceptions of their teacher communication behaviors than students of public schools because of their higher academic achievement.

Other studies have shown that the classroom learning environment variables predict students' cognitive outcomes (Fraser, 2002). For example, Frumkin and Murphy (2007), using the TCBQ, reported a positive relationship between students' perceptions of teacher communication behavior and final class grades. More specifically, higher final grades were received by students who perceived their teachers to be more challenging and controlling; a result consistent with other studies of high school students who valued teachers who provided challenging instruction (Irving, 2004). Likewise, among a New Zealand sample of high school students (Winheller, Hattie \& Brown, 2013), higher ratings of teacher interest and quality predicted greater academic outcomes.

We found no differences between the students' perceptions of their male and female science teachers (hypothesis 4) and no interaction between student gender and teacher gender (hypothesis 5). This contrasts to previous TCBQ studies which found higher ratings for teachers of the same gender as the students (Cirillo \& Herbel-Eisenmann, 2006; Frumkin $\&$ Murphy, 2007). However, not enough research is available about the differences between teacher communication behaviors according to the gender of the teacher in Brazil. We could hypothesize that, conventionally, female teachers are considered more warm and supportive than their male counterparts. But our results do not support this interpretation.

We consider that the results reported in this study with respect to student gender, teacher gender, type of school, and subject might be explained by real-world structural relations; though this is a matter for future studies. Classroom 
interactions occur quickly, making it difficult for teachers and students to be aware of them (She \& Fisher, 2000). The TCBQ can give teachers feedback that may help them recognize their own behaviors and contribute towards the development of positive classroom learning environments.

While this study found acceptable fit of the data to the TCBQ model and consistency with previous international studies, some improvements could yet be made. Improved fit of the TCBQ may be found with the use of alternative rating scales; for example, agreement ratings (i.e., giving an indication of endorsement) may provide more precision than the current frequency (especially given weaknesses in human perception of frequency) scale of the TCBQ (Brown, 2004). Furthermore, given the existence of versions of the TCBQ in different languages, an important next step would be to investigate the measurement invariance of the TCBQ's items across countries (Byrne \& Watkins, 2003; Meredith, 1993; Millsap, 2005). The establishment of measurement invariance or non-invariance of the TCBQ items would allow cross-cultural research and may shed light on further improvements to the TCBQ itself.

\section{References}

American Educational Research Association, American Psychological Association, \& National Council on Measurement in Education (1999). Standards for educational and psychological testing. Washington, DC: American Educational Research Association.

Brown, G. T. L. (2004). Measuring attitude with positively packed self-report ratings: Comparison of agreement and frequency scales. Psychological Reports, 94(3), 1015-1024.

Byrne, B. M., \& Watkins, D. (2003). The issue of measurement invariance revisited. Journal of Cross-Cultural Psychology, 34(2), 155-175.

Chen, H., Chang, W., \& Chang, H. (2002). Different gender students' perceptions of classroom climate in a trial of a teacher developed interdisciplinary module. Proceedings of the National Science Council, Republic of China - Part D: Mathematics, Science and Technology Education, 12(3), 79-90.

Cirillo, M., \& Herbel-Eisenmann, B. (2006). Teacher communication behavior in the mathematics classroom. In S. Alatorre, J. L. Cortina, M. Sáiz, \& A. Méndez (Eds.), Annual Meeting of the North American Chapter of the International Group for the Psychology of Mathematics Education: Vol. 2. (pp. 497-498). Mérida, México: Universidad Pedagógica Nacional.

Dorman, J. (2002). Classroom environment research: Progress and possibilities. Queensland Journal of Educational Research, $18(2), 112-14$.

Fagot, B. (1981). Male and female teachers: Do they treat boys and girls differently? Sex Roles, 7(3), 263-271.

Fan, X., \& Sivo, S. A. (2007). Sensitivity of fit indices to model misspecification and model types. Multivariate Behavioral Research, 42(3), 509-529.

Fraser, B. J. (2002). Learning environments research: Yesterday, today and tomorrow. In S. C. Goh \& M. S. Khine (Eds.), Studies in educational learning environments: An international perspective (pp. 1-26). River Edge, NJ: World Scientific.
Fraser, B. J., Giddings, G. J., \& McRobbie, C. R. (1995). Evolution and validation of a personal form of an instrument for assessing science laboratory classroom environments. Journal of Research in Science Teaching, 32(4), 399-422.

Frumkin, L. (2006). Does increasing communication through visual learning environments enhance student perceptions of lecturers? International Education Journal, 7(5), 688-698.

Frumkin, L., \& Murphy, A. (2007). Student perceptions of lecturer classroom communication style. European Journal of Social Sciences, 5(3), 45-60.

Hambleton, R. K., \& Patsula, L. (1999). Increasing the validity of adapted tests: Myths to be avoided and guidelines for improving test adaptation practices. Journal of Applied Testing Technology, 1(1), 1-12.

Harkness, J. A., \& Schoua-Glusberg, A. (1998). Questionnaires in translation. In J. A. Harkness, F. J. R. Van De Vijver, \& P. P. Molher (Eds.), Cross-cultural survey methods (pp. 87- 127). Hoboken, NJ: John Wiley \& Sons.

Hoyle, R. H., \& Duvall, J. L. (2004). Determining the number of factors in exploratory and confirmatory factor analysis. In D. Kaplan (Ed.), The SAGE Handbook of Quantitative Methodology for Social Sciences (pp. 301-315). Thousand Oaks, CA: Sage.

Hu, L., \& Bentler, P. M. (1999). Cutoff criteria for fit indexes in covariance structure analysis: Conventional criteria versus new alternatives. Structural Equation Modeling, 6(1), 1-55.

Idiris, S. \& Fraser, B. J. (1994, December). A study of learning environments in agricultural science classrooms in Nigeria. Paper presented at the Annual Conference of the Australian Association for Research in Education (AARE), The University of Newcastle, New South Wales.

International Test Commission - ITC (2000a). International guidelines for test use. Retrieved from www.intestcom. org/ itc_projects.htm

International Test Commission - ITC (2000b). Test adaptation guidelines. Retrieved from www.intestcom.org/itc_projects. $\mathrm{htm}$

Irving, S. E. (2004). The development and validation of a student evaluation instrument to identify highly accomplished mathematics teachers. (Unpublished doctoral dissertation). University of Auckland, Auckland.

Khine, M. S., \& Fisher, D. L. (2003). Teacher-student interactions in science classrooms in Brunei. Journal of Classroom Interaction, 38(2), 21-28.

Marsh, H. W., Hau, K., \& Grayson, D. (2005). Goodness of fit in structural equation models. In A. Maydeu-Olivares \& J. J. McArdle (Eds.), Contemporary psychometrics: A festschrift for Roderick P. McDonald (pp. 275-340). Mahwah, NJ: Lawrence Erlbaum Associates.

Marsh, H. W., Hau, K.-T., \& Wen, Z. (2004). In search of golden rules: Comment on hypothesis-testing approaches to setting cutoff values for fit indexes and dangers in overgeneralizing $\mathrm{Hu}$ and Bentler's (1999) findings. Structural Equation Modeling, 11(3), 320-341.

Matos, D. A. S. (2006). Students' perceptions of science teachers' communication behavior. A percepção dos alunos do comportamento comunicativo do professor de ciências. (Unpublished Master's Thesis). Universidade Federal de Minas Gerais, Belo Horizonte. 
Meredith, W. (1993). Measurement invariance, factor analysis and factorial invariance. Psychometrika, 58(4), 525-543.

Millsap, R. E. (2005). Four unresolved problems in studies of factorial invariance. In A. Maydeu-Olivares \& J. J. McArdle (Eds.), Contemporary psychometrics: A festschirift for Roderick P. McDonald (pp. 153-171). Mahwah, NJ: Lawrence Erlbaum.

Muthén, L. K., \& Muthén, B. O. (2006). Mplus (Version 4.2). Los Angeles, CA: Authors.

Özay, E., Kaya, E., \& Sezek, F. (2004). Application of a questionnaire to describe teacher communication behaviour and its association with students in science in Turkey. Journal of Baltic Science Education, 2(6), 15-21.

Sebela, M. P. (2003). Using teacher action research to promote constructivist learning environments in mathematics classes in South Africa. (Unpublished doctoral dissertation). Curtin University of Technology, Bentley.

She, H. C. (1998). Interaction between different gender students and their teacher in junior high school biology classes. Journal of Proceedings of the National Science Council, Part D: Mathematics, Science, and Technology Education, 8, 16-21.

She, H. C. (1999). Students' knowledge construction in small groups in the 7th grade biology laboratory: Verbal communication and physical engagement. International Journal of Science Education, 21(10), 1051-1066.

She, H. C. (2000). The interplay of a biology teacher's beliefs, teaching practices and gender-based student-teacher classroom interaction. Educational Research, 42(1), 100-111.

She, H. C. \& Fisher, D. (2000). The development of a questionnaire to describe science teacher communication behavior in Taiwan and Australia. Science Education, 84(6), 706-726.

She, H. C., \& Fisher, D. (2002). Teacher communication behavior and its association with students' cognitive and attitudinal outcomes in science in Taiwan. Journal of Research in Science Teaching, 39(1), 63-78.
Stake, J., \& Katz, J. (1982). Teacher-pupil relationships in the elementary school classroom: Teacher-gender and pupil-gender differences. American Educational Research Journal, 19(3), 465-471.

Stapleton, L. M. (2006). An assessment of practical solutions for structural equation modeling with complex sample data. Structural Equation Modeling, 13(1), 28-58.

Waldrip, B. G., \& Fisher, D. L. (2000). The development and validation of a learning environment questionnaire using both quantitative and qualitative methods. Journal of Classroom Interaction, 35(2), 25-37.

Walker, S. L. (2004). Learning environment research: A review of the literature (Learning Environments Monograph No. 2). San Marcos, TX: Texas State University. Retrieved from http:// uweb.txstate.edu/ sw36/monographs

Watzlawick, P., Beavin, J. H., \& Jackson, D. D. (1991). Pragmática da comunicação humana: um estudo dos padrões, patologias e paradoxos da interação. São Paulo: Cultrix.

Winheller, S., Hattie, J. A., \& Brown, G. T. L. (2013). Factors influencing early adolescents' maths achievement: High quality teaching rather than relationships. Learning Environments Research, 16(1), 49-69.

Wubbels, T., \& Levy, J. (1991). A comparison of interpersonal behaviour of Dutch and American teachers. International Journal of Intercultural Relations, 15(1), 1-18.

Wubbels, T., Levy, J., \& Brekelmans, M. (1997). Paying attention to relationships. Educational Leadership, 54, 82-86.

Wubbels, T. \& Brekelmans, M. (2005). Two decades of research on teacher-student relationships in class. International Journal of Educational Research, 43(1), 6-24.

Yilmaz Tüzün, O. (2006). Validation and use of Teacher Communication Behavior Questionnaire in Elementary Schools. Hacettepe University Journal of Education, 31, 234-243. 


\section{Appendix A}

Scales and items from the English-version of the Teacher Communication Behavior Questionnaire (TCBQ), developed by She \& Fisher (2000, 2002), and scales and items from the Portuguese-version of the TCBQ, adapted by Matos (2006).

\section{English-version}

\section{Challenging}

1. This teacher asks questions that require me to provide steps or ways of solving problems.

2. This teacher asks questions that make me think hard about things that I have learned in class.

3. This teacher asks questions that require me to carefully analyze information in order to answer.

4. This teacher asks questions that require me to use a judgment to answer.

5. This teacher asks questions that require me to apply what I have learned in class in order to answer.

6. This teacher asks questions that require me to integrate information that I have learned.

7. This teacher asks questions that require me to understand what I have learned in class in order to answer.

8. This teacher asks questions that require me to give explanations in my own words.

\section{Encouragement and Praise}

9. This teacher asks for my opinions during discussions.

10. This teacher encourages me to discuss the answers to questions.

11. This teacher encourages me to discuss my ideas with other students.

12. This teacher encourages me to express my opinions about a topic.

13. This teacher praises me for asking a good question.

14. This teacher praises my answers.

15. This teacher uses my ideas as part of the lesson.

16. This teacher uses my answer as part of the explanation of the lesson.

\section{Non-Verbal Support}

17. This teacher nods his/her head to show his/her understanding of my opinion.

18. This teacher nods his/her head to show support while I am struggling to answer a question.

19. Without speaking, this teacher indicates support for me through his/her facial expression.

20. Without speaking, this teacher supports me when I have a problem through his/her facial expression.

21. Without speaking, this teacher shows he/she understands my opinion through his/her facial expression.

22. Without speaking, this teacher shows his/her enthusiasm about my answer through his/her facial expression.

23. Without speaking, this teacher shows his/her enthusiasm about my question through his/her facial expression.

24. Without speaking, this teacher shows his/her support through his/her eyes.

\section{Understanding and Friendly}

25. This teacher trusts me.

26. This teacher is willing to explain things to me again.

27. If I have something to say, this teacher will listen.

28. This teacher realizes when I do not understand.

29. This teacher is patient with me.

30. This teacher is friendly to me.

31. This teacher is someone I can depend on.

32. This teacher cares about me.

\section{Controlling}

33. This teacher's standards of behavior are very high.

34. This teacher expects me to obey his/her instructions.

35. This teacher insists that I follow his/her rules.

36. This teacher insists that I do everything(s) he/she tells me to do.

37. This teacher demands that I do exactly as I am told.

38. This teacher does not allow me to do things differently from what he/she expect.

39. This teacher makes very clear to me the standard of behavior expected of all students in this class.

40. This teacher demands that I listen to instructions. 


\section{Portuguese-version}

\section{Desafio}

1. Esse(a) professor(a) faz perguntas que exigem que eu estabeleça passos ou maneiras de resolver problemas.

2. Esse(a) professor(a) faz perguntas que me fazem pensar com empenho sobre coisas que eu aprendi na aula.

3. Esse(a) professor(a) faz perguntas que exigem que eu analise a informação cuidadosamente para poder responder.

4. Esse(a) professor(a) faz perguntas que exigem que eu faça um julgamento sobre coisas que eu aprendi na aula para responder.

5. Esse(a) professor(a) faz perguntas que exigem que eu aplique o que eu aprendi na aula para poder responder.

6. Esse(a) professor(a) faz perguntas que exigem que eu incorpore a informação que eu aprendi.

7. Esse(a) professor(a) faz perguntas que exigem que eu entenda o que eu aprendi na aula para poder responder.

8. Esse(a) professor(a) faz perguntas que exigem que eu dê explicações com as minhas próprias palavras.

\section{Encorajamento e elogio}

9. Esse(a) professor(a) pede minhas opiniões durante as discussões.

10. Esse(a) professor(a) me encoraja a discutir as respostas para as perguntas.

11. Esse(a) professor(a) me encoraja a discutir minhas idéias com outros alunos.

12. Esse(a) professor(a) me encoraja a expressar minhas opiniões sobre um assunto.

13. Esse(a) professor(a) me elogia por fazer uma boa pergunta.

14. Esse(a) professor(a) elogia minhas respostas.

15. Esse(a) professor(a) usa minhas idéias como parte da aula.

16. Esse(a) professor(a) usa minhas respostas como parte da explicação da aula.

\section{Apoio não-verbal}

17. Esse(a) professor(a) balança sua cabeça em gesto afirmativo para mostrar sua compreensão da minha opinião.

18. Esse(a) professor(a) balança sua cabeça em gesto afirmativo para mostrar apoio enquanto eu estou me esforçando para responder uma pergunta.

19. Sem falar, esse(a) professor(a) demonstra pela sua expressão facial que me apóia.

20. Sem falar, esse(a) professor(a) demonstra pela sua expressão facial que me apóia, quando eu tenho um problema.

21. Sem falar, esse(a) professor(a) demonstra pela sua expressão facial que ele/ela entende minhas opiniões.

22. Sem falar, esse(a) professor(a) demonstra pela sua expressão facial seu entusiasmo sobre minhas respostas.

23. Sem falar, esse(a) professor(a) demonstra pela sua expressão facial seu entusiasmo sobre minhas perguntas.

24. Sem falar, esse(a) professor(a) demonstra apoio através dos seus olhos.

\section{Compreensão e relação amigável}

25. Esse(a) professor(a) confia em mim.

26. Esse(a) professor(a) se dispõe a explicar coisas para mim de novo.

27. Esse(a) professor(a) vai escutar se eu tenho algo a dizer.

28. Esse(a) professor(a) percebe quando eu não entendo.

29. Esse(a) professor(a) é paciente comigo.

30. Esse(a) professor(a) é amigável comigo.

31. Esse(a) professor(a) é alguém com quem eu posso contar.

32. Esse(a) professor(a) se preocupa comigo.

\section{Controle}

33. Esse(a) professor(a) exige padrões de comportamento muito altos dos alunos.

34. Esse(a) professor(a) espera que eu obedeça suas instruções.

35. Esse(a) professor(a) insiste que eu siga suas regras.

36. Esse(a) professor(a) insiste que eu faça tudo que ele/ela me diz para fazer.

37. Esse(a) professor(a) exige que eu faça exatamente como me foi falado.

38. Esse(a) professor(a) não me permite fazer coisas diferentemente daquilo que ele/ela espera.

39. Esse(a) professor(a) deixa muito claro para mim o padrão de comportamento esperado de todos alunos nessa aula.

40. Esse(a) professor(a) exige que eu escute as instruções dele(a). 